\title{
Mao's steps in Monroe's backyard: towards a United States-China hegemonic struggle in Latin America?
}

\author{
Os passos de Mao na trilha de Monroe: rumo a uma competição \\ hegemônica entre Estados Unidos e China na América Latina?
}

http://dx.doi.org/10.1590/0034-7329201400202

JOSE LEÓN-MANRÍQUEZ*

LUIS F. ALVAREZ**

Rev. Bras. Polit. Int. 57 (special edition): 9-27 [2014]

\section{Introduction}

This article addresses the triangular relations between the United States, China and Latin America. The main goal is to assess whether a regional hegemonic struggle between China and the US is emerging. Furthermore we are interested in evaluating the impact of China's inroads in Latin America within the broader framework of Sino-US relations. We posit that, contrary to what could be expected given the United States' historical hegemony of Latin America, growing Chinese influence in this region has not led to a dispute between both powers. This quietness would be explained by three factors: the US political negligence towards Latin America in the Post-Cold War, the focus of Sino-Latin American relations on economic affairs, and the scanty relevance of the region in the priorities of Washington-Beijing relations.

In order to explain the so far peaceful Sino-US coexistence, we examine the current regional balance in three sections. The first offers a context for the United States' historical influence in Latin America and its policy for the region in the Post-Cold War. The second section details the economic inroads China has made into this region and explains its growing trade leverage. In the third section we place Latin America in the broader context of the China-US bilateral agenda. In doing so we examine the relative importance of this region for both powers and how this marginal position has contributed to the pragmatic approach they have taken.

\footnotetext{
* Universidad Autónoma Metropolitana, Unidad Xochimilco, Mexico City, Mexico (joseluisleonm@hotmail.com).

** Department of Geography, University of California, Los Angeles, United States (lfalvarez@ucla.edu).
} 


\section{From Central American jungles to free trade agreements: the US-Latin American relations in the Post-Cold War}

From a historical viewpoint, United States-Latin America relations have featured three main traits. Firstly, the US hegemony over the region has been a historic, structural and continuous reality at least since the early $19^{\text {th }}$ century. Secondly, these relations have undergone recurring cycles of interest and disdain from the United States to Latin America. Thirdly, long periods of coercive influence have alternated with shorter moments of more expedient ties (Booth 1995). Just to underline the toughness of US policy towards the region, the late Argentinean scholar Gregorio Selser (2001) documented hundreds of US interventions, especially in the Caribbean Basin.

During the Cold War (1945-1990), Latin America became one of the diverse US theaters for containment of the Soviet Union. Virtually every political movement with an agenda of social transformation came to be seen as Soviet-supported and a consequent threat to the US national security. Washington intervened systematically in the region, overthrowing progressive governments in Guatemala (1954), the Dominican Republic (1966), Chile (1973), and Grenada (1983). The US also intervened unsuccessfully to abort the Cuban revolution in 1961. In 1979, the Sandinista revolution triumphed in Nicaragua. Ronald Reagan's administration (1981-1989) implemented an aggressive strategy to derail the Sandinista regime and the left-wing revolutions in Guatemala and El Salvador.

With Soviet influence declining in the US closest area of influence, and after the invasion of Panama in 1989, president George H. W. Bush (1989-1993) crafted a more pragmatic approach towards the Central American left. This attitude, as well as the fatigue of revolutionary forces after years of intensive struggle, favored negotiations between Central American governments and revolutionary movements such as the Farabundo Martí Front for National Liberation-Frente Farabundo Martí para la Liberación Nacional (FMLN) — in El Salvador and the Guatemalan National Revolutionary Unity-Unidad Revolucionaria Nacional Guatemalteca (URNG) - in Guatemala.

Once pacification in Central America was achieved, the US focused its foreign policy in other areas of the world, such as the USSR successor states, Eastern Europe, and the Middle East. In Latin America, the emphasis of US policy shifted from geopolitics to geoeconomics. In the 1990s, trade and investment issues prevailed over political and military involvement. The US strategy for Latin America became focused on the defense of pluralist regimes, economic reforms and free trade agreements (FTAs). The idea that the market mechanism should be extensively used to revamp Latin American economies, themselves lashed by statism, inflation, and protectionism, came to be known as the Washington Consensus (Williamson 1990).

The new US approach for Latin America was initially embodied in the Enterprise for the Americas Initiative (EAI), announced by Bush on June 27, 1990. 
The main three strategies of EAI were to create a free trade area spanning all of the Americas, from Anchorage to the Tierra del Fuego; a loan program and a proposed US\$ 1.5 billion multilateral investment fund to be administered by the InterAmerican Development Bank; and a program of conditional official debt relief, with interest payments on the reduced debt to be reimbursed on local currencies. This and other foreign policy pronouncements underlined the US preference of trade over aid (The Development GAP 1992).

Perhaps the boldest combination of the Washington Consensus and the normative preference for free markets was the signature, in 1994, of the North American Free Trade Agreement (NAFTA), which included Mexico. After this, it was expected that other Latin American nations would follow the Mexican example. This belief, however, proved to be less than streamlined.

In the early 1990s Latin American elites' interpretation of the emerging correlation of power created yet another consensus. The leading idea was that a unipolar world had risen after the Cold War. With the exception of Cuba and perhaps Brazil, Latin American rulers thought that no other regional or world power had the economic, political, diplomatic or military strength to be a real counterweight to the US. At the time, this diagnosis was largely present in the international actions of most governments in Latin America. For instance, Mexico underwent a radical departure from its traditional distrust towards the US, invoking a cooperation attitude labeled as "the spirit of Houston." In an extreme formulation of this acquiescence, Argentinean President Carlos S. Menem proudly declared that his country had a "carnal relationship" with the United States (Barcelona 1992).

This perception of an almighty US was coupled by the attitude of extra-regional actors during the 1990s: while the USSR collapsed, the European Union, Japan and China either stayed aloof or engaged Latin America with extreme caution. In the words of Peter H. Smith, during the 1990s the US achieved "hegemony by default" in Latin America (Smith 1996, 34).

In this context the US continued its pursuit of continental integration through the Free Trade Area of the Americas (FTAA). In the First Summit of the Americas, held in December 1994 in Miami, the Heads of State and Government of 34 countries (Cuba did not participate), agreed to achieve substantial progress toward the FTAA by 2000 and to finish negotiations by 2005 . Formal negotiations were launched in April 1998. After substantive summitry and several ministerial meetings, FTAA aborted in 2005, in the Fourth Summit of the Americas in Mar del Plata, Argentina. Amidst fierce criticisms from the most radical Latin American leaders, the US initiative sank.

What explains this Washington failure? First, a wave of leftist governments, ranging from social democracy to nationalism and populism, won successive elections in Latin American countries. This Latin American "new left" did not necessarily share the enthusiasm for free-marketry, the neoliberal credo and the admiration for the US that center or rightist governments featured in the previous decades the 1990s. 
Secondly, skepticism on liberalism and FTAs was reinforced when Latin America resumed economic growth in the early 2000s after two decades of shaky economic performance (see Figure 1). Such countries as Argentina, Brazil, Peru and Venezuela underwent at least half a decade of sustained economic growth, and the region recovered rapidly from the Great Recession (2008-2010). This performance was sparked, to a great extent, by China's voracious demand of commodities. Regardless of its causes, renewed growth strengthened Latin America's international assertiveness.

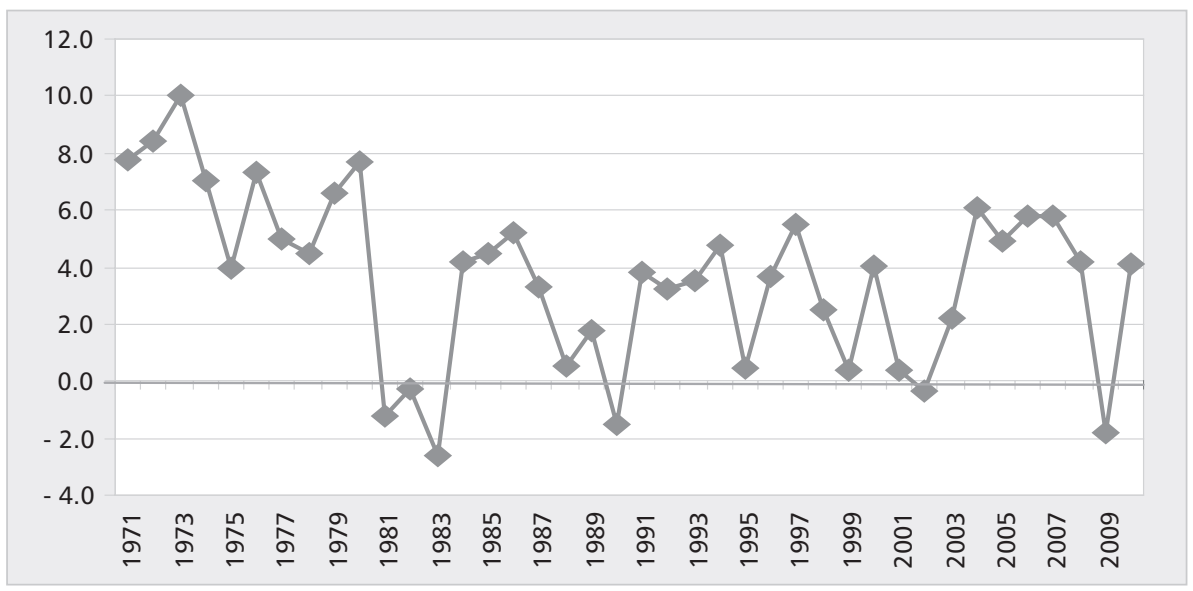

Figure 1. Latin America and the Caribbean: GDP growth, 1970-2010 (percentages, constant prices).

Source: ECLAC, various years.

All of a sudden the unipolar world that seemed self-evident a decade earlier came into question after September 11, 2001 and the ensuing US interventions in Afghanistan (2001) and Iraq (2003). These developments raised doubts on the real span of US hegemony and strained Washington's relations with key political partners such as the European Union and China. At the regional level FTAA was blocked, mostly under the table, by Brazilian center-left leadership (Lyons and Meckler 2001). As Brazil, other Southern Cone countries increasingly drifted away from US economic and political influence. Most of these countries have been quite enthusiastic to play the Chinese card as a means of diversifying their foreign economic relations.

The fissure between the US and South America is not only ideological or political, but mostly economic. At first glance, relations between the US and Latin America are stronger than ever. For instance, total trade between the two parties rose from US\$ 115.1 billion in 1990 , to US\$ 339.7 billion in 2000, to US\$ 849.7 billion in 2012 (USCB 2013). In relative terms, Latin America also gained relevance for US foreign trade: in 1990, the region accounted for 13.3\% 
of US exports and $12.9 \%$ of US imports. By 2009, the respective shares increased to $22.1 \%$ and $18.1 \%$ respectively (ECLAC 2013 ).

A closer look, though, shows a less rosy picture. First of all, the Mexico factor is increasingly relevant. In 1990, $51 \%$ of US trade with Latin America took place with Mexico; by 2012, the Mexican share rose to 58\% (USCB 2013). Secondly, Table 1 shows that the US is still the main trade partner for imports of most Latin American countries; however, its relevance as outlet for South American exports is decreasing. The US ranks $2^{\text {nd }}$ for Brazil and Chile; $3^{\text {rd }}$ for Argentina, $7^{\text {th }}$ for Uruguay and $11^{\text {th }}$ for Paraguay.

US economic influence in Mexico, Central America and the Caribbean is less questioned. Both in terms of exports and imports, the United States is the main partner of Mexico, Central America, Colombia, Ecuador, and Venezuela. These countries' trade with the US fluctuates between 30 and $80 \%$ of the total (ECLAC 2011a, 14). The trend toward regionalization in this area is taking place not only in terms of trade and investment, but also in phenomena such as migration and drug-trafficking. In other words, the US economic presence in Latin America seems to follow a pattern of concentric circles in which the US economic influence is directly proportional to geographical contiguity.

Table 1. US position in trade ranking with Latin America by value (2000-2009).

\begin{tabular}{|l|c|c|c|c|}
\hline & \multicolumn{2}{|c|}{ Exports } & \multicolumn{2}{c|}{ Imports } \\
\hline Argentina & 2000 & 2009 & 2000 & 2009 \\
\hline Brazil & 2 & 3 & 2 & 2 \\
\hline Paraguay & 1 & 2 & 1 & 1 \\
Uruguay & 6 & 11 & 4 & 6 \\
Chile & 3 & 7 & 3 & 4 \\
Colombia & 1 & 2 & 1 & 1 \\
Venezuela & 1 & 1 & 1 & 1 \\
Costa Rica & 1 & 1 & 1 & 1 \\
Guatemala & 1 & 1 & 1 & 1 \\
\hline Mexico & 1 & 1 & 1 & 1 \\
\hline
\end{tabular}

Source: ECLAC (2011a, 21).

Given the failure of FTAA, the US has ironed out bilateral FTAs within its comfort economic zone. This approach has led to FTAs with Chile (2004), Central America and the Dominican Republic (CAFTA-DR 2006) and Peru (2009). FTAs with Colombia and Panama were ratified by the US Congress in October 2011. While the US has turned to trade bilateralism after 2005, it seems to lack a clear strategy for those Latin American countries not included in its network of bilateral trade agreements. 
From our viewpoint, US policy towards Latin America during the last two decades has been rather limited, lacking diplomatic strategies and comprehensive social and political perspectives. Pegging US-Latin American relations to a FTA's negotiations is barely a sound policy. The Initiative for the Americas, the aborted FTAA and the Washington Consensus have proved insufficient to manage the increasing complexity of US-Latin America relations. While economic liberalism took momentum in the 1990s, since the early 2000s the social and political agenda has regained relevance in Latin America. Washington fixation with marketization and free trade as its main Latin America policy does not seem to have grasped the spirit of the new times.

Moreover, after 9/11, US neglect for Latin America increased due to Washington's focus on the Middle East. This power vacuum has certainly facilitated the emergence of China as a vigorous actor in Latin America. Indeed, it has made some analysts predict the impending demise of the Monroe Doctrine (Castañeda 2009). How important is Latin America in the context of bilateral relations between the US and China? How are different US political and economic interests reacting to Chinese presence in Latin America? What has been the position of Barack Obama's administration on this issue? Does this policy entail continuity or change from previous administrations? These and other questions are addressed in the following sections of this article.

\section{A zero-sum game? Trajectories of China's growing influence in Latin America}

China's relationship with Latin America can be characterized as having recently awoken from a long period of latency. The ties between both sides of the Pacific Ocean go back five centuries. Throughout the Spanish Colonial period in Latin America there was a steady trade link between the Viceroyalty of New Spain (1521-1821, present-day Mexico) and Asia (Spate 1979). In the second half of the $19^{\text {th }}$ century there were massive Chinese migrations to the United States, Peru, Cuba and Mexico. Pushed by the need of protecting its citizens abroad, the declining Middle Kingdom established official diplomatic relations with some Latin American countries (Hearn and León-Manríquez 2001).

After a long period of instability in the $20^{\text {th }}$ century (end of the Empire of Heaven, civil war, Sino-Japanese War), Maoist revolution took power in 1949. As a result, China would be divided in two de-facto states: the People's Republic of China (PRC) in Mainland China, and the Republic of China (ROC) in Taiwan. Both of them still claim to be the legitimate government. In the early years of the Cold War the United States supported Taiwan and was suspicious of the developments in the PRC, which initially adopted the Soviet Union as its model.

This alliance between the two communist countries would be short-lived. In the early 1960s the Sino-Soviet split drove these two states against each other. 
China's drift from the Soviet sphere of influence allowed it to craft a foreign policy that did not adhere strictly to a bipolar paradigm and emphasized a Third-Worldcentered agenda (Kochan 1972; Shao 1979).

This meant paving a way beyond both Soviet and American spheres while simultaneously gaining influence among Third World countries — often supporting armed liberation movements in places well beyond its immediate vicinity such as Angola, Mozambique and Maoist factions in Latin America. In a region of military dictatorships, anti-communist ideologies and pro-US policies, the PRC was mostly seen as a disruptive force (Johnson 1970; Jackson 1995).

In fact, Latin America, and in particular Central America and the Caribbean, was a contested region for Chinese foreign policy as long as it represented an extension of the conflict for international recognition between Taiwan and the PRC. Taipei won gain diplomatic recognition among many countries in the region, where it opened plenty of diplomatic representations. In fact, to this day Taiwan's links with Central America and the Caribbean represent the core of its shrinking diplomatic connections with the international community (Haro Navejas 2011, 205).

China's foreign policy undertook a gradual but drastic turn during the next decade. The rapprochement with the United States in the early 1970s made easier for Latin American countries such as Chile, Brazil and Mexico to open embassies in Beijing and break relations with Taipei. Thus China garnered support for its sovereignty claims in the "One China Policy" through the expansion of bilateral relationships with leading Latin American countries. These were strengthened through its involvement in a number of multilateral projects in the region, such as the signature of Protocol 2 of the Treaty of Tlatelolco in 1973 and the support of the Contadora Group's peace negotiations in the 1980s. These episodes notwithstanding, China only fully engaged Latin America after the end of the Cold War.

Since then, PRC's relations with Latin America have rapidly intensified. While official diplomatic liaisons, sustained trade and investment are relatively recent, they have increased apace with China's rapid economic rise. The reforms undertaken by Deng Xiaoping starting in 1979 transformed China from mostly an agrarian society into the world's second largest economy. As many other regions in the world, Latin America has found itself on the receiving end of China's rise, which has brought with it a host of new opportunities and potential pitfalls.

In the last few years, Latin American countries have followed two different economic patterns in their relations with the PRC. For the sake of simplicity we shall label them Trajectory A and Trajectory B (León-Manríquez 2011). The former is featured by some South American countries. It has been propelled by China's need for oil, minerals and food in quantities that exceed its internal production capacity. This demand generated a commodity boom between 2003 and 2008 (Coxhead and Jayasuriya 2010). Many South American countries refocused their trading relationships to cater China's expanding need for raw materials. Thus, 
Chile and Peru supply China with copper, Brazil with soy complex and iron ore, Argentina with soy beans and meat, and Venezuela with oil.

Despite the commodity boom, the economic relationship of South American countries with China can be understood as long-term uncertainty versus shortterm gains. Many producers in this region find themselves at a crossroads where they must decide between a sustainable model with slow returns and a short-term payoff that risks endangering future development capacity. This point is illustrated by the trade-offs faced by Argentinian producers in weighing the immediate gains from exporting vast amounts of soy to China versus the likely environmental degradation from over-reliance on this crop (Malena 2011, 273).

The risks of overdependence in commodity production have become quite clear after the end of the boom in 2008. Akin to putting all of their eggs (and copper, pig iron and soy) in one basket, South American producers such as Argentina and Chile have felt the sudden decrease in commodity trade as the main shock to their economies (Ocampo 2009). In trying to weather the global financial crisis, they have found their over-reliance on commodity exports detrimental to their long-term stability.

This concern is not too far-fetched; indeed, cycles of booms and busts have been scattered through the entire history of Latin American economies. For Trajectory A countries, there are latent risks stemming from the deterioration of the terms of trade. By the mid-2000s, many South American countries were experiencing trade surpluses with China, which exports are increasingly sophisticated from the technological viewpoint. In 2011, nine out of the 12 members of the Latin American Integration Association-Asociación Latinoamericana de Integración (ALADI) - recorded a trade deficit with China.

Trajectory B has more to do with the industrial transformation of China and its impact upon Mexico and Central America. This trajectory places manufactures (mostly assembled in maquiladora industries) in direct competition with Chinese exports. Since they target the same markets as those from Mexico and other countries, it is increasingly difficult for the latter to compete on price, as their wage rates are much higher than China's.

Mexico can be understood as a paradigmatic case of Trajectory B, although many of the Central American nations have followed a similar path. As a country with a manufacturing sector that makes up almost three quarters of its exports, Mexico has faced increasing competition from China in the United States market. This market has long been of vital importance for Mexico, and currently receives $80 \%$ of its outgoing trade. However, Mexico has been losing ground to China, which displaced it as the second largest supplier to the US since 2003 (LeónManríquez 2011, 167).

China has developed increasing sophistication in its exports and currently over $90 \%$ of them consist of manufactures. The United States plays a crucial part in China's export economy, as it is the destination for $18 \%$ of its total exports (WTO 2012). These factors explain the increasingly competitive relationship 
between Mexico and China, which has been skewed in the latter's favor due mainly to labor cost differentials.

Beyond competition for export markets, the relationship between China and Trajectory B countries in Latin America is complicated by the growing trade imbalance between these parties. Currently many of these countries have a trade deficit with China that has been steadily growing to levels of 1 to 14.5 in the case of Mexico; 1 to 65 with Nicaragua; and 1 to 111 with El Salvador, to name a few (León-Manríquez 2011, 167-168).

Table 2 shows a picture of several Latin American countries and their changing trade relationship with China in the last decade. The main trend, which applies across the board, is that the vast majority of Latin American countries have swiftly increased their trade with the PRC. In the realm of exports, only Uruguay and Paraguay show an unchanging relationship with China as a trading partner. Every other country featured the PRC in a higher ranking as a trading partner in 2009 than nine years earlier.

The most notable cases are perhaps those where China is now the number one export partner, such as Brazil and Chile. In the 2000s both countries underwent an important shift in the direction of their exports. This is evidenced by China's status as top trading partner in both cases after ranking $12^{\text {th }}$ for Brazil and $5^{\text {th }}$ for Chile in 2000, respectively. Even when China did not become the top trading partner, it led other countries to remodel their trading relationships within a decade. In this respect, countries such as Colombia, Venezuela and Costa Rica are remarkable examples due to the significant ranking differential in nine years. In fact, out of all the countries in the table, only Paraguay and Guatemala had China as a trading partner outside of the top-ten by 2009. This shows how Latin American exports have concentrated on China as one of the premier export destinations.

Table 2. China position in trade ranking with Latin America by value (2000-2009).

\begin{tabular}{|l|c|c|c|c|}
\hline & \multicolumn{3}{|c|}{ Exports } & \multicolumn{2}{c|}{ Imports } \\
\hline Argentina & 2000 & 2009 & 2000 & 2009 \\
\hline Brazil & 6 & 4 & 4 & 3 \\
\hline Paraguay & 12 & 1 & 11 & 2 \\
Uruguay & 15 & 15 & 3 & 1 \\
Chile & 4 & 4 & 7 & 3 \\
Colombia & 5 & 1 & 4 & 2 \\
Venezuela & 36 & 6 & 9 & 2 \\
Costa Rica & 35 & 2 & 18 & 3 \\
Guatemala & 30 & 2 & 15 & 3 \\
Mexico & 43 & 25 & 19 & 2 \\
\hline
\end{tabular}

Source: ECLAC (2011b, 19). 
On the imports side, the effect is even more pervasive: all Latin American countries in the chart had China in a higher trade ranking in 2009 than they did at the turn of the millennium. The annualized growth rate of imports to Latin America between 2006 and 2010 was $22.8 \%$. This is remarkable considering those of the region's traditional partners, the US and the EU, were 5.9\% and 9.2\% respectively (ECLAC 2011c, 94). While in 2000 China was a top-3 ranked import source only for Paraguay, in 2009 every single Latin American country shown in the table ranked China in this category. This means that while most of these countries redirected a significant portion of their exports to China, all of them received a much larger import volume from this country.

Significant as it may be, the rapid rise of Latin American trade with China masks a fundamental imbalance. On the one hand Latin America has been thoroughly affected by trade with China, whether through the commodity boom or through the huge import influx. On the other hand, while it is clear that China's growth incites a swift demand for commodities, Latin America is only one of several sources that fuel this growth. In other words, while this trade relationship is now crucial for Latin America, it is not necessarily so much for the PRC. This is visible in the composition of China's trading partners and the position occupied by Latin American countries in this ranking. This shows that China is pursuing a multidimensional diversification strategy that minimizes risk and ensures uninterrupted supplies (Klare 2012, 3).

Figure 2 illustrates the lack of reciprocity in the trade relationship between China and Latin America. It shows how, in spite of China's rise in the trade ranking with Latin American countries, this region does not yet figure as one of its main partners. As a single source of imports for China, neighboring Japan tops the list with $12.7 \%$. It is closely trailed by the 27 -country aggregate of the European Union, which collectively make up $12.1 \%$ of China's imports. In third place South Korea, another of China's neighbors, accounts for $9.9 \%$, while Taiwan has $8.3 \%$ and the Great China (i.e., mostly Hong Kong), 7.7\%. What is remarkable in this figure is that, in spite of all the hype caused about Latin America's surge in exports to China, this region is nowhere to be found near the top list of its import sources.

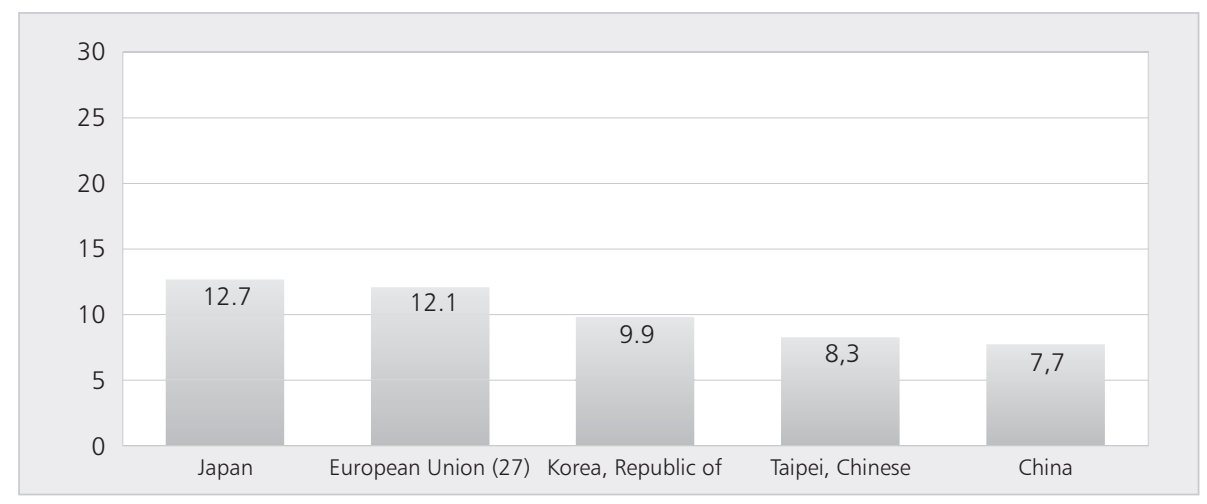

Figure 2. China's imports in 2010, top 5 sources by share (\%).

Source: WTO country profiles, accessed on April 2012. 
This imbalance in the relationship between both sides of the Pacific can be explained by several factors. The first is that China's expansion transcends the export capacities of Latin America. A second reading is that China's strategy is one of diversification. In its process of opening to the world, China touches down on a diversity of regions and broadens its economic and diplomatic horizons to include many regions of the world, one of which is Latin America. Chinese ventures in Africa and its immediate sphere of influence, Southeast Asia, are other well documented cases of this strategy (Holslag 2007; Lum et al. 2008). Thirdly, China's incursion into Latin America carries with it the additional consideration that it is making inroads into a zone historically laden with competing geopolitical interests. In this respect China's strategy seems to be engaging in the region without making an outright challenge to the US hegemony. This cautious approach is reflected in the White Paper on Latin America published by the Chinese government in 2008 (MFAPRC 2008).

So far China's actions suggest it is playing a long game in Latin America that includes multiple but gradual arrangements in the region. Inasmuch as Sino-US relations are already fraught with tensions on multiple fronts, China seems unwilling to add a struggle over Latin America to the mix. In the following section we will examine in greater detail the role that this region has come to play in the global bilateral relations between the two great powers.

\section{Dynamic but still low-profile-Latin America's place in global Sino-US relations}

Given the historic trends and the sudden appearance of China in the United States "backyard," it is worth analyzing Washington's reaction to this new phenomenon. Generally speaking, Washington response has been surprisingly sanguine in comparison to previous incursions of foreign powers in Latin America. Anyhow, it is necessary to avoid a common mistake in many progressive perspectives on the US, which see the United States as a rational, unified actor. In actuality, policymaking in the US (as elsewhere) is the outcome of the interaction amongst different political forces, material interests and ideological views that overlap and negotiate each other when formulating foreign policy.

Hence, reactions on Chinese engagement on Latin America have been divided in at least two groups. In this case, the soft-liners are integrated by the Presidency, the Department of State, and liberal lawmakers and scholars. Predictably, hard-liners include certain sectors of the Department of Defense and Congress, conservative scholars, and some of the usually fear-mongering think tanks.

Strange as it may seem, prudent views have prevailed in the Executive branch. This cautious attitude may be explained by the continuity of the engagement policy towards China that has been an enduring feature of William Clinton (1993-2001), George W. Bush (2001-2009) and Barack Obama's (2009-) diplomacy. Clearly, 
the US does not wish to open additional battlefronts in its overloaded bilateral agenda with Beijing.

In various statements by State Department officials there is a surprisingly tolerant stance on China's involvement in Latin America. Such statements are usually very careful and alien to the aggressive and anti-communist rhetoric of, say, Ronald Reagan's presidency. Soft-liners argue that China's interest in Latin America is mostly a market-driven process and deny that Chinese political activities in the hemisphere are aimed at undermining US hegemony. There is, however, a slight concern that Beijing could get too close to left-wing leaders such as Hugo Chávez, Raúl Castro or Evo Morales.

Let us point to the example of Roger Noriega, well-known for its roughness during his tenure as US permanent representative to the Organization of American States (OAS), between 2001 and 2003. Notwithstanding this trajectory, in a Congressional hearing in 2005, Noriega, by then appointed Assistant Secretary of State for Western Hemisphere Affairs of George W. Bush administration (quoted by Lewis 2007,39$)$, declared:

We continue to monitor closely China's outreach to Latin America as we monitor it around the world. We seek to ensure that this activity does not run counter to US goals in the region and is compatible with this hemisphere's hard-won progress toward representative democracy. Nevertheless, it is important to measure China's intentions, in part, by the close alliances that it pursues in this region. Obviously, if it chooses to align itself with disruptive forces, such as Castro's Cuba and others, then it would be of great concern to the United States.

Either under Republican or Democrats, the Department of State presents noteworthy continuity. Addressing a different audience from Noriega's, Barack Obama's Deputy Secretary of State, William Burns (2011) stated:

Given the economic dynamism in both sides of the Pacific, it is no surprise that Asia and Latin America have also recognized each other's potential. We should not fear Asia's economic interest in our hemisphere, provided the relationships are transparent and the rules are respected.

Beyond the Department of State, hawkish opinions permeate the top echelons of the US political system. Indeed, some documents written by belligerent lawmakers and scholars evoke the McCarthyist discourse of the 1950s. For instance, California's Republican representative Dana Rohrabacher has referred to the Chinese government as "hating democracy" and has forecasted that the administration of the Panama Canal by Hong Kong-based firm Hutchinson Whampoa will lead to Communist domination of the Canal and the country itself within a few years (Sullivan and Villarreal 2001, 12). 
In yet another statement of distress, in 2005 Dan Burton, a senior member of the House Subcommittee on the Western Hemisphere (quoted by Lewis 2007, 35-36), stressed:

I believe we should be cautious and view the rise of Chinese power as something to be counterbalanced or contained, and perhaps go so far as to consider Chinass actions in Latin America as the movement of a hegemonic power into our hemisphere.

Views on the dangers of China encroaching in Latin America are also present in academia and think tanks. On July 21, 2005, in his testimony before the USChina Economic and Security Review Commission of the US Congress, Albert Santoli $(2005,175)$, director of the Asia-America Initiative warned that China has been advancing "unrestricted warfare" against the US. This would include leveraging opposition to Washington in Latin America, developing cyber-warfare capabilities and control of key trade points like the Panama Canal. His proposal for action was straightforward: "US policymakers should make a thorough review of the Monroe Doctrine to see how it may be applied to today's developments in the region."

Perhaps in view of all these hard-liners' apprehensions, the George W. Bush administration (2001-2009) decided to address its concerns on Latin America with China's top diplomatic echelons. In April, 2006, Thomas Shannon, who succeeded Roger Noriega as Assistant Secretary of State for Western Hemisphere Affairs, undertook a visit to China. That was the first time that a top official of the Department of State travel to Beijing with the single goal of having a dialogue on Latin America. After Shannon's trip and during the Obama administration, there have been other rounds of Sino-US dialogue on Western Hemisphere issues.

Since the presidential campaign in 2008, Barack Obama and his advisers on foreign affairs have tried to put more attention on relations between China and Latin America. In September 26, 2008, during his first debate with Republican candidate John McCain, Obama (quoted by Erikson 2011) tackled the issue in the following terms:

We've got challenges, for example, with China, where we are borrowing billions of dollars. They now hold a trillion dollars' worth of our debt. And they are active...in regions like Latin America, and Asia, and Africa. The conspicuousness of their presence is only matched by our absence, because we've been focused on Iraq.

Once in office, democrats have trailed the China-Latin America connection in shifting terms. For instance, in May 2009, Hillary Clinton, Secretary of State during the first Obama administration (quoted by Keyes 2009) uttered a concerned attitude: 
I have to say that I don't think in today's world, where it's a multipolar world, where we are competing for attention and relationships with at least the Russians, the Chinese, the Iranians, that it's in our interest to turn our backs on countries in our own hemisphere... And, in fact, if you look at the gains, particularly in Latin America, that Iran is making and China is making, it's quite disturbing. I mean, they are building very strong economic and political connections with a lot of these (leftist Latin American) leaders. I don't think that's in our interest.

These words would be, at first glance, the evidence of a harder Democrat stance on the issue. Nevertheless, in a visit to Beijing in 2010, Obama's Assistant Secretary of State for Western Hemisphere Affairs, Arturo Valenzuela, declared:

China certainly is not of concern, it certainly is not a threat... In fact, we see China providing Latin America with many more opportunities to grow their economies, to provide better jobs, to increase the standard of living. [...] We both benefit from a stable, prosperous Latin America that engages much more in world trade. So this is a win-win for both countries (People's Daily 2010).

Regardless occasional animosity against China, cautious positions on China's involvement with Latin America have prevailed in most of the Executive branch. Such a stance is easier to carry out to the extent that China does not seem eager to create an influence area in Latin America. This explains why China's relations with the region have not sparked the frantic reactions that USSR ties with Cuba or Nicaragua used to spur among top policymakers in Washington in the 1980s. Unlike the USSR during the Cold War, Chinese strategy is much more economic than ideological or geopolitical.

Moreover, Sino-Latin American links should be understood as part of a global Beijing's effort to develop mostly economic ties with peripheral areas. Doubtless, China is becoming increasingly relevant for Latin America's foreign trade, as we showed in the preceding section. Despite some Latin American countries' fantasies, the region is still far from a priority in terms of the broader Sino-US agenda. Looked form a global perspective, Chinese relation with Latin America may be blooming, but still are modest.

An example of the relative remoteness of Latin America in the global bilateral agenda is to be found in the outcomes of the Fourth Round of the US-China Strategic and Economic Dialogue. Held on May 3-4, 2012, the dialogue was chaired by Secretary Hillary Clinton and State Councilor Dai Bingguo, representative of Chinese President $\mathrm{Hu}$ Jintao. The Joint Statement issued at the end of the meeting (USCSED 2012), only mentions Latin America in the context of other bilateral sub-dialogues such as Policy Planning, Africa, South Asia, and Central Asia.

In the US Congress, things are not too different. Up to 2013, none of the almost 100 hearings of the influential US-China Economic and Security Review 
Commission (USCC), established in 2000, dealt explicitly with Latin America. Despite the referred bellicosity of some individual congresspersons, the 2012 Annual Report to the Congress (USCC 2012), contains six chapters and 32 recommendations aimed at improving the US-China relations. Latin America is completely absent in the report's analysis and proposals.

This is not to say that global Sino-US relations are smooth in every domain. The bilateral agenda is full of contentious issues that can be grouped in "concentric circles." The first one has to do with diverging perspectives on political entities that are located in China's area of influence; those are the cases of Taiwan, North Korea and Iran. A second priority is the bilateral economic relationship, which includes the US trade deficit vis-à-vis China, Washington's pressures for PRC's currency revaluation, the potential dispute for global energy resources, and the role that the two powers will play in the processes of economic integration in East Asia. The third category comprises a heterogeneous set of issues, headed by the U.S. concern for increasing Chinese military spending, as well as various issues related to human rights.

During the Obama administration, and particularly since 2011, when it proclaimed the new "Pivot to Asia Policy," the relations with China have been at the forefront of politics in the US (Clinton 2011). Indeed, this turned into one of the crucial issues in the 2012 presidential election, when China-bashing became standard fare in political campaigns. Republican candidates in the primary presidential election were particularly vocal on China. Congresswoman Michelle Bachman, adopted the catchphrase "Hu's your daddy?" to warn about Chinese influence in the United States. Tycoon Donald Trump went farther, bluntly stating that "China is raping this country (Burns 2011)."

Once victorious in the primary Republican elections, candidate Mitt Romney emphasized China's character as a "cheater" and Obama's inability to step up to it. Furthermore, he vowed to declare the PRC a currency manipulator in his first day in office as well as imposing tariff penalties that could spark a trade war (Harwood 2012). Perhaps in response to accusations of being soft on China, the Obama administration decided to lodge a complaint with the WTO against China on automobile subsidies (Landler 2012). The timing of this complaint, filed less than 50 days before the elections, further underscores the crucial role that the bilateral relation with China has come to play not only for the US government, but for the electorate as well.

The bilateral agenda between Washington and Beijing will ultimately have great influence in the $21^{\text {st }}$ century world order. As China gets more economic, political and military power, it is very likely that bilateral tensions with the US will increase. Although Latin America is certainly part of the bilateral equation between both parties, so far it has played a marginal role. It seems that neither Beijing nor Washington wish to poison their somehow stressed relations because of Latin America. But reality is dynamic. In the middle-run, concerns on China's 
rise and increasing pressures from US hard-liners could transform Latin America in a scenario of geopolitical dispute between the two great powers.

\section{Conclusions}

The bulk of China's presence in Latin America is driven by economic goals and is part of a global strategy aimed at ensuring the flows of energy, raw materials and food that are necessary for the continuity of PRC's development. Beyond economic ties, Chinese presence in Latin America does not seek, at least for the moment, to create a regional counter-hegemony to the US in Latin America. Thus, it seems inaccurate to speak of a new bipolarity or a second edition of the Cold War in the Western Hemisphere. To paraphrase Mao Zedong, there are contradictions between the US and China, but they have not resulted in antagonisms.

A second conclusion is that the US lacks, so far, goals and instruments to cope with the growing presence of China in Latin America. Despite political and economic changes within the US, Washington's discourse on Latin America looks anchored in the early 1990s. Stress on democracy, privatization and free trade might have seem coherent strategies then, but many changes have occurred in the world, the US and Latin America. A comprehensive US strategy to regain presence and prestige in Latin America is still needed, but there is no evidence that it will be built soon. While US ties with Mexico and Central American nations are stronger due to trade, migration and shared security concerns, this not a guaranteed state of affairs. On the other hand, after the breakdown of the FTAA there has been a considerable lack of initiative in the US policy towards South American countries. Emerging trade patterns have brought many of them further from the US and closer to China.

A third relevant point is, we think, that overall US-China bilateral relations are becoming increasingly stressed. These tensions derive from the logic of hegemonic succession cycles that have characterized the international system for centuries. Hence our prognosis is that Sino-US conflict will continue to grow in the incoming years. In this big picture Latin America features a growing but still marginal relevance. Nevertheless, if bilateral tensions continue growing in the next decades, the region could become a theatre of global disputes between Monroe and Mao's heirs.

\section{Bibliographic references}

Barcelona, Eduardo. 1992. Relaciones Carnales. Buenos Aires: Grupo Editorial Planeta.

Booth, John A. 1995. "Central America and the United States: Cycles of Containment and Response," in United States Policy in Latin America: A Decade of Crisis and Challenge, 1981-1991, edited by J. D. Martz. Lincoln, Nebraska: University of Nebraska Press.

Burns, Alexander. 2012. “GOP sees red over China.” Politico, May 242011 [cited September 20 2012]. Available from http://www.politico.com/news/stories/0511/55559.html. 
Burns, William J. 2012. "Remarks at World Affairs Councils of America National Conference". Washington, D.C.: Department of State, November 4 [cited September 10 2012]. Available from <http://www.state.gov/s/d/2011/176667.htm>.

Castañeda, Jorge G. 2009. “Adios, Monroe Doctrine,” The New Republic, December 28.

Clinton, Hillary. 2011. "America’s Pacific Century,” Foreign Policy, November.

Coxhead, Ian, and Sisira Jayasuriya. 2010. "China, India and the Commodity Boom: Economic and Environmental Implications for Low-income Countries," World Economy 33 (4):525-551.

ECLAC. 2011a. The United States and Latin America and the Caribbean. Highlights of economics and trade. Santiago de Chile: Economic Commission for Latin America and the Caribbean (ECLAC).

ECLAC. 2011b. People's Republic of China and Latin America and the Caribbean.

Ushering in a new era in the economic and trade relationship. Santiago de Chile: ECLAC.

ECLAC. 2011c. Panorama de la inserción internacional de América Latina y el Caribe. La región en la década de las economías emergentes. Santiago de Chile: ECLAC.

ECLAC. 2013. SIGCI Database. [cited September 10 2012] Available from http://www.cepal. org/comercio/serieCP/eclactrade/serie_spanish_102.html

Erikson, Daniel P. 2011. "Conflicting US Perceptions of China's Inroads in Latin America," In China Engages Latin America. Tracing the Trajectory, edited by A. Hearn and J. L. LeónManríquez. Boulder, $\mathrm{CO}$ and London: Lynne Rienner.

Haro Navejas, Francisco. 2011. "China's Relations with Central America and the Caribbean States: Reshaping the Region" in China Engages Latin America. Tracing the Trajectory, edited by A. Hearn and J. L. León-Manríquez. Boulder, CO and London: Lynne Rienner.

Harwood, John. 2012. "The Electoral Math of Romney's Stance on Trade With China," The New York Times [cited September 12 2012]. Available from http://www.nytimes. com/2012/03/23/us/politics/mitt-romneys-stance-on-china-trade.html?pagewanted=all.

Hearn, Adrian, and José Luis León-Manríquez, eds. 2011. China Engages Latin America. Tracing the Trajectory. Boulder, CO and London: Lynne Rienner.

Holslag, Jonathan. 2007. Chinese Resources and Energy Policy in Sub-Saharan Africa. Brussels: Directorate-General for External Policies of the Union.

Jackson, Steven F. 1995. "China's Third World Foreign Policy: The Case of Angola and Mozambique, 1961-93.” The China Quarterly 142:388-422.

Johnson, Cecil. 1970. Communist China and Latin America, 1959-1967. New York: Columbia University Press.

Keyes, Charley. 2009. "Clinton warns of Iranian, Chinese gains in Latin America." CNN, May 1, [cited September 24 2012]. Available at <http://www.cnn.com/2009/POLITICS/05/01/ clinton.latin.america/index.html>.

Klare, Michael. 2012. “China’s imperial predicament.” Le Monde Diplomatique, September, 3. Kochan, Ran. 1972. "Changing Emphasis in the Non-Aligned Movement." The World Today 28 (11):501-508. 
Landler, Mark. 2012. "Filing Trade Suit, Obama Raps Romney on China," (September 17, 2012). The New York Times 2012 [cited September 17 2012]. Available from http://hecaucus.blogs.nytimes.com/2012/09/17/filing-trade-suit-obama-raps-romney-onchina/?hp\&pagewanted=print.

León-Manríquez, José Luis. 2011. "China’s Relations with Mexico and Chile: Boom for Whom?,” in China Engages Latin America. Tracing the Trajectory, edited by A. Hearn and J. L. León-Manríquez. Boulder, CO and London: Lynne Rienner.

Lewis, Peter M. 2007. "La presencia de China en América Latina. Un tema controvertido." Estudios Internacionales 156:27-53.

Lum, Thomas, Wayne M. Morrison, and Bruce Vaughn. 2008. “China's 'Soft Power' in Southeast Asia.” CRS Report for Congress. Washington, D.C.: Congressional Research Service.

Lyons, John, and Laura Meckler. 2011. "China Shadow Follows Obama in Latin Trip." The Wall Street Journal, Business Section March 19.

Malena, Jorge Eduardo. 2011. "China and Argentina: Beyond the Quest for Natural Resources," in China Engages Latin America. Tracing the Trajectory, edited by A. Hearn and J. L. LeónManríquez. Boulder, $\mathrm{CO}$ and London: Lynne Rienner.

MFAPRC. 2008. China's Policy Paper on Latin America and the Caribbean. Beijing: Ministry of Foreign Affairs of the People's Republic of China.

Ocampo, José Antonio. 2009. "Latin America and the global financial crisis." Cambridge Journal of Economics 33 (4):703-724.

People's Daily. 2010. "China 'not a threat' in L. America”. 2012. People's Daily Online, August 19, 2010 [cited September 24 2012]. Available from http://english.peopledaily.com. cn/90001/90776/90883/7109092.html.

Santoli, Albert, 2005. "China's Strategic Reach into Latin America." Hearing before the US-China Economic and Security Review Commission. July 21.

Selser, Gregorio. 2001. Cronología de las intervenciones extranjeras en América Latina: 1899-1945. Mexico City: UNAM.

Shao, Kuo-kang 1979. "Chou En-lai's Diplomatic Approach to Non-Aligned States in Asia: 1953-60”. The China Quarterly (78):324-338.

Smith, Peter H. 1996. “The United States, Regional Integration, and the Reshaping of the International Order" in Cooperation or Rivalry? Regional Integration and the Pacific Rim, edited by S. Nishijima and P. H. Smith. New York: Westview Press.

Spate, O. H. K. 1979. The Spanish Lake. Canberra, Australia: ANU Press

Sullivan, Mark P., and M. Angeles Villarreal. 2001. "Panama-US Relations.” CRS Issue Brief for Congress. Washington, D.C.: Congressional Research Service.

The Development Gap. 1992. “The Enterprise for the Americas Initiative: Description and Update”. Washington, D.C.: The Development Group for Alternative Policies, Inc.

USCB. 2013. "US Trade in Goods by Country." Washington D.C.: United States Census Bureau. [cited February 4 2012]. Available from http://www.census.gov/foreign-trade/balance/ USCC. 2012 Report to Congress. 2012. Washington, D.C.: US-China Economic and Security Review Commission. 
USCSED. 2012. "Joint Statement on the US-China Strategic and Economic Dialogue Outcomes of the Strategic Track". Washington. D.C.: Department of State.

Williamson, John. 1990. The Progress of Policy Reform in Latin America. Washington DC: Institute for International Economics.

WTO. 2012. "China Trade Profile 2012”. World Trade Organization. April.

Submitted July 8, 2013

Accepted February 5, 2014

\begin{abstract}
Contrary to what could be expected given the United States' historical hegemony of Latin America, growing Chinese influence in this region has not led to a dispute between China and the US. Despite activism of hard-line groups in the United States, both parties have faced the issue with noticeable pragmatism. This attitude could be explained by three variables: the US political negligence towards Latin America in the Post-Cold War, the focus of Sino-Latin American relations on economic rather than geopolitical or ideological affairs, and the scanty relevance of the region in the top priorities of overall Washington-Beijing relations.
\end{abstract}

Keywords: China-Latin America relations; Latin America foreign affairs; US-Latin America relations.

\title{
Resumo
}

Ao contrário do que se poderia esperar devido à hegemonia histórica dos Estados Unidos na América Latina, a crescente influência chinesa na região não levou a uma disputa entre China e Estados Unidos. Apesar do ativismo de grupos linha-dura nos Estados Unidos, ambas as partes têm enfrentado a questão com pragmatismo perceptível. Essa atitude pode ser explicada por três variáveis: a negligência política americana para a América Latina no pós-Guerra Fria, o foco das relações sino-latino-americana sobre economia, em vez de assuntos geopolíticos ou ideológicos, e a relevância escassa da região no topo de prioridades das relações globais de Washington-Pequim.

Palavras-chave: relações China-América Latina; Relações Internacionais da América Latina; relações América Latina-Estados Unidos. 